\title{
Specific Regulation of NRG1 Isoform Expression by Neuronal Activity
}

\author{
Xihui Liu, ${ }^{1,3}$ Ryan Bates, ${ }^{1}$ Dong-Min Yin, ${ }^{1}$ Chengyong Shen, ${ }^{1}$ Fay Wang, ${ }^{4}$ Nan Su,,${ }^{4}$ Sergei A. Kirov, ${ }^{5}$ Yuling Luo, ${ }^{4}$ \\ Jian-Zhi Wang, ${ }^{3}$ Wen-Cheng Xiong, ${ }^{1,2}$ and Lin Mei ${ }^{1,2}$ \\ ${ }^{1}$ Institute of Molecular Medicine and Genetics and ${ }^{2}$ Department of Neurology, Georgia Health Sciences University, Augusta, Georgia 30912, ${ }^{3}$ Department of \\ Pathophysiology, Key Laboratory of Neurological Disorders of Education Ministry, Tongji Medical College, Huazhong University of Science and \\ Technology, Wuhan, China 430030, ${ }^{4}$ Advanced Cell Diagnostics, Inc., Hayward, California 94545, and ${ }^{5}$ Department of Neurosurgery, Georgia Health \\ Sciences University, Augusta, Georgia 30912
}

Neuregulin 1 (NRG1) is a trophic factor that has been implicated in neural development, neurotransmission, and synaptic plasticity. NRG1 has multiple isoforms that are generated by usage of different promoters and alternative splicing of a single gene. However, little is known about NRG1 isoform composition profile, whether it changes during development, or the underlying mechanisms. We found that each of the six types of NRG1 has a distinct expression pattern in the brain at different ages, resulting in a change in NRG1 isoform composition. In both human and rat, the most dominant are types III and II, followed by either type I or type V, while types IV and VI are the least abundant. The expression of NRG1 isoforms is higher in rat brains at ages of E13 and P5 (in particular type V), suggesting roles in early neural development and in the neonatal critical period. At the cellular level, the majority of NRG1 isoforms (types I, II, and III) are expressed in excitatory neurons, although they are also present in GABAergic neurons and astrocytes. Finally, the expression of each NRG1 isoform is distinctly regulated by neuronal activity, which causes significant increase in type I and IV NRG1 levels. Neuronal activity regulation of type IV expression requires a CRE cis-element in the $5^{\prime}$ untranslated region(UTR) that binds to CREB. These results indicate that expression of NRG1 isoforms is regulated by distinct mechanisms, which may contribute to versatile functions of NRG1 and pathologic mechanisms of brain disorders such as schizophrenia.

\section{Introduction}

NRG1 is a family of growth factors that has been implicated in the development of neural crest cells (Mei and Xiong, 2008) and GABAergic circuitry (Woo et al., 2007; Fazzari et al., 2010; Ting et al., 2011). It is also implicated in the migration (Anton et al., 1997; Rio et al., 1997), neurite outgrowth (BerminghamMcDonogh et al., 1996; Mahanthappa et al., 1996), and synapse formation ( $\mathrm{Li}$ et al., 2007) of excitatory neurons. NRG1 suppresses LTP (Huang et al., 2000; Ma et al., 2003; Kwon et al., 2005; Pitcher et al., 2008) and the activity of pyramidal neurons (Wen et al., 2010), probably via promoting GABA release from interneurons (Chen et al., 2010; Wen et al., 2010). The diverse functions of NRG1 are contributed in part by a large number of NRG1 isoforms. In humans, NRG1 has $>30$ isoforms that can be grouped into six types (I-VI), each with a distinct N-terminal

\footnotetext{
Received Oct. 10, 2010; revised April 19, 2011; accepted April 28, 2011.

Author contributions: X.L., W.-C.X., and L.M. designed research; X.L., R.B., D.M.Y., C.S., F.W., N.S., and Y.L. performed research; S.A.K., Y.L., W.-C.X., and L.M. contributed unpublished reagents/analytic tools; X.L., W.-C.X., and L.M. analyzed data; X.L., J.-Z.W., and L.M. wrote the paper.

This work was supported by in part by grants from the NIH, National Alliance for Research on Schizophrenia and Depression, and China Scholarship Council. We thank the anonymous reviewers for their constructive comments and critiques, Dr. Riqiang Yan of Cleveland Clinic for human brain samples, and members of the Mei laboratory for discussion.

Correspondence should be addressed to Dr. Lin Mei, Institute of Molecular Medicine and Genetics and Department of Neurology, Georgia Health Sciences University, Augusta, GA 30912. E-mail: Imei@georgiahealth.edu.

DOI:10.1523/JNEUROSCI.5317-10.2011

Copyright $\odot 2011$ the authors $\quad 0270-6474 / 11 / 318491-11 \$ 15.00 / 0$
}

region (Falls, 2003; Mei and Xiong, 2008). Generation of the enormous numbers of NRG1 isoforms in humans is thought to be mainly contributed by alternative splicing of $>30$ exons of the gene. Recent studies suggest that its expression may also be controlled by 5' promoters of different types of NRG1 (Steinthorsdottir et al., 2004; Tan et al., 2007). The NRG1 isoforms differ in domain structure and expression levels in various tissues/cells during neural development and in adult. Mice carrying mutations that inactivate particular isoforms show distinct phenotypes, in support of the notion that NRG1 isoforms have distinct functions (Kramer et al., 1996; Fischbach and Rosen, 1997; Meyer et al., 1997; Gerlai et al., 2000; Wolpowitz et al., 2000; Rimer et al., 2005; Bjarnadottir et al., 2007).

In the nervous system, the genes of NRG1 and its receptor ErbB4 are associated with schizophrenia (Stefansson et al., 2002; Yang et al., 2003; Nicodemus et al., 2006; Norton et al., 2006; Silberberg et al., 2006; Law et al., 2007; Mei and Xiong, 2008), bipolar disorder (Thomson et al., 2007; Goes et al., 2008; Prata et al., 2009; Zuliani et al., 2011), and positive symptoms of psychosis in late-onset Alzheimer's disease (Go et al., 2005). NRG1 signaling may play a role in epilepsy, as the ErbB4 gene was disrupted in a patient with early myoclonic encephalopathy (Backx et al., 2009). Finally, NRG1 appears to be neuroprotective in stroke (Shyu et al., 2004; Xu et al., 2004).

Although six types of NRG1 have been identified in humans, little is known about the composition profile and whether it changes during development, nor is it clear whether they are all expressed in 
rodents. We attempted to address these questions in this study. In addition, we determined in what neurons or cells NRG1 isoforms are expressed. Finally, we investigated mechanisms of the regulation of their expression by neuronal activity. Results demonstrate that expression of NRG1 isoforms is regulated by complex mechanisms, which may contribute to versatile functions of NRG1 and pathology of brain disorders including schizophrenia.

\section{Materials and Methods}

Animal. Sprague Dawley rats of either sex were purchased from Harlan. Experiments with animals were approved by the Institutional Animal Care and Use Committee of Georgia Health Sciences University.

Primary cortical neuron culture. Cortical neurons were cultured as described previously (Woo et al., 2007). Briefly, cerebral cortex of E18 Sprague Dawley rats was dissociated in HBSS containing $0.1 \%$ trypsin. Cells were seeded on poly-L-lysine-coated 12 -well plates at high density $\left(8 \times 10^{5} /\right.$ well $)$ in DMEM media with $10 \%$ FBS. Four hours later, the media was replaced with Neurobasal supplemented with 2\% B27, $2 \mathrm{~mm}$ glutamine, $1 \mathrm{IU} / \mathrm{ml}$ penicillin, and $100 \mu \mathrm{g} / \mathrm{ml}$ streptomycin. At day in vitro 12 (DIV12), most, if not all, cells under our condition were neurons (supplemental Fig. $\mathrm{S} 1 A, B$, available at www.jneurosci.org as supplemental material). In some experiments, neurons (DIV3-DIV12) were treated with 50 $\mathrm{mm} \mathrm{KCl}$ or $100 \mu \mathrm{m}$ kainic acid (KA) for $6 \mathrm{~h}$ before RNA extraction.

Primary astrocyte culture. Astrocytes were cultured as described previously with modification (McCarthy and de Vellis, 1980). Briefly, cerebral cortex was of P3 Sprague Dawley rats were dissociated in HBSS containing $0.1 \%$ trypsin. Cells were seeded on poly-L-lysine-coated $100 \mathrm{~mm}$ culture dishes at high density $\left(1 \times 10^{7} /\right.$ dish $)$ in DMEM medium with $10 \% \mathrm{FBS}, 1 \mathrm{IU} / \mathrm{ml}$ penicillin, and $100 \mu \mathrm{g} / \mathrm{ml}$ streptomycin. Medium was changed every $3 \mathrm{~d}$, when dishes were shacked and washed extensively three times with PBS to remove oligodendrocytes, microglia, and neurons. At DIV10, $>90 \%$ glia cells were GFAP-positive astrocytes (supplemental Fig. S1C, available at www.jneurosci.org as supplemental material). Astrocytes were trypsinized and replated on 12-well plates until confluency was $>90 \%$, before being treated with $50 \mathrm{~mm} \mathrm{KCl}$ for $6 \mathrm{~h}$.

Isolation of total RNA. Total RNA was isolated from cultured neurons or astrocytes by using RNeasy mini kit (Qiagen) and from brain samples by using Trizol (Invitrogen), purified by using RNeasy mini kit (Qiagen). In some experiments, adult rats were treated for $4 \mathrm{~h}$ with saline (control) or KA $(10 \mathrm{mg} / \mathrm{kg}$ body weight, i.p.). Epileptic seizures were observed within $1 \mathrm{~h}$ after KA injection (Sperk, 1994).

$R T-q P C R$. Equal amounts of total RNAs ( $1 \mu \mathrm{g}$ for cultured neurons and 4 $\mu \mathrm{g}$ for brain tissue) were reverse transcribed by random hexamer-primers using SuperScript III reverse transcriptase (Invitrogen). One of two hundred (1/40 for type VI) samples of resulting cDNA was analyzed by qPCR in triplicates using SYBR Green/ROX (Fermentas) on Chromo 4 (Bio-Rad). Forward primers corresponded to sequences in type-specific exons and reverse primers were in either Ig or EGF exons. Primers are exon-spanning for most PCRs except for those for the EGF domain that should amplify all NRG1 isoforms. mRNA levels were normalized to $\beta$-actin that was assayed simultaneously on the same reaction plate. To measure the absolute mRNA
B
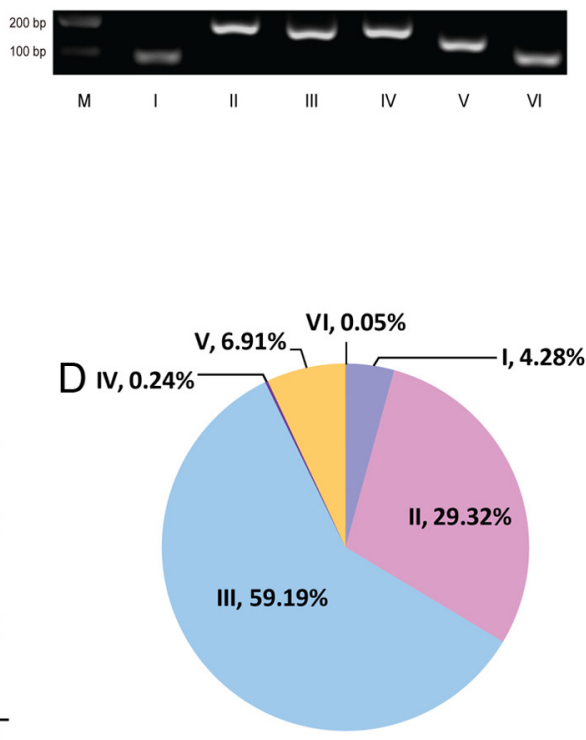

$\mathrm{F}$

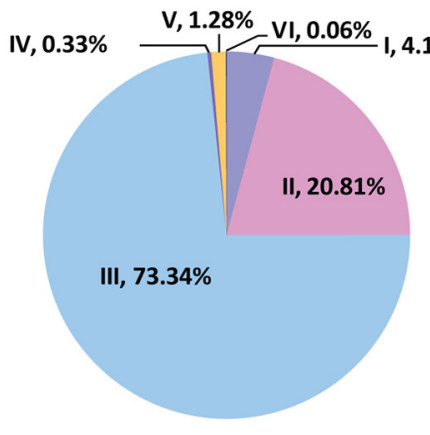

Figure 1. Distinct expression patterns of NRG1 types in the human cerebral cortex. $\boldsymbol{A}$, Diagram of NRG1 gene structure. Typespecific forward primers (indicated by arrows) for each type were located in unique exons, whereas reverse primers were located in either Ig or EGF domain. Forward primers were also designed for EGF domain. $\boldsymbol{B}$, Agarose gel electrophoresis of RT-qPCR 列 difference in PCR efficiencies, band intensity did not faithfully indicate relative amount. C, Different levels of NRG1 types in the

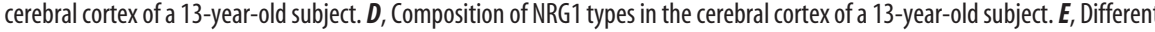
levels of NRG1 types in the cerebral cortex of a 60 -year-old subject. The copy numbers per microgram total RNA of each type NRG1 were $1.67 \pm 0.17 \times 10^{4}$ (type I), $8.31 \pm 1.17 \times 10^{4}$ (type II), $2.93 \pm 0.23 \times 10^{5}$ (type III), $1.31 \pm 0.06 \times 10^{3}$ (type IV), $5.12 \pm$ $0.73 \times 10^{3}$ (type V), and $227 \pm 226$ (type VI). F, Composition of NRG1 types in the cerebral cortex of a 60 -year-old subject.

copy number of a given isoform, each qPCR plate included three samples (in triplicates) that contained known copy numbers (i.e., $10^{2}, 10^{4}$, and $10^{6}$ ) of isoform-specific templates, to generate a standard curve. Supplemental Figure S2 A (available at www.jneurosci.org as supplemental material) lists all primers used in the study.

Dual luciferase assay. 5'UTRs of type I and IV NRG1s were amplified by PCR using as template BAC clone RP11-957C19 and RP11-957H23, respectively (Roswell Park Cancer Institute). They were subcloned into pGL2 vector, upstream of the firefly luciferase gene, to generate Iwt-Luc and IVwt-Luc. Mutant luciferase constructs were generated by mutagenesis (Stratagene) and verified by sequencing. SH-SY5Y human neuroblastoma cells were cotransfected by electroporation (Lonza) with a pGL2-based luciferase construct with pRL-TK that expresses Renilla luciferase under the control of the TK promoter (ratio, 20:1). Twelve hours after transfection, cells were treated with vehicle or $50 \mathrm{~mm} \mathrm{KCl}$ for $12 \mathrm{~h}$ before lysis. Activities of firefly and Renilla luciferases were assayed by a microplate luminometer (Tropix TR717). Firefly luciferase activity was normalized by Renilla luciferase activity to eliminate sample handling 
A

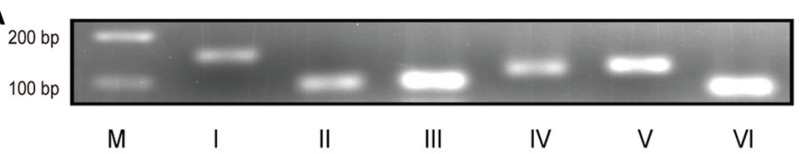

$\mathrm{B}$

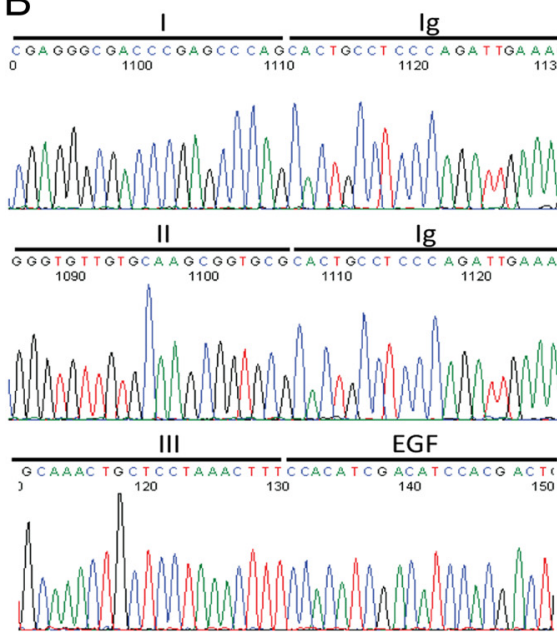

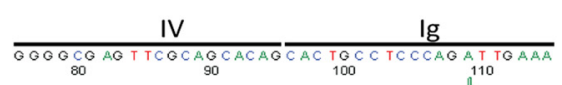

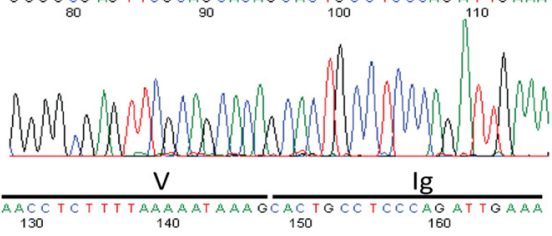

130
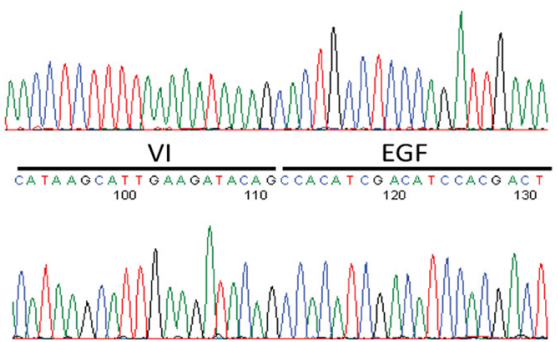

Figure 2. Expression of all six types of NRG1 in rat brain. RT-qPCR was performed using the same strategy as described in Figure 1A. A, Agarose gel electrophoresis of RT-qPCR products. Total RNA of E18 rat brain was used as template in RT-qPCR with specific primers. Products were resolved on $3 \%$ agarose gel and visualized by ethidium bromide staining. Bands were at the anticipated molecular weight. Due to potential difference in PCR efficiencies, band intensity did not faithfully indicate relative amount. $B, D N A$ sequence analysis of RT-qPCR products. RT-qPCR products were purified and subcloned into pGEM-T easy vector (Promega) for sequencing with $\mathrm{T} 7$ primer. Shown were partial DNA sequences of respective domains.

variation. Supplemental Figure S2 B (available at www.jneurosci.org as supplemental material) lists all primers used in the study.

Fluorescent in situ hybridization. Rats were perfused with room temperature $4 \%$ formaldehyde in PBS. Brain samples were postfixed in $4 \%$ formaldehyde in PBS for $18-24 \mathrm{~h}$ at $4^{\circ} \mathrm{C}$, dehydrated, and embedded in paraffin. Brain sections ( $5 \mu \mathrm{m}$ in thickness) were subjected to dual fluorescent in situ hybridization (FISH) by using RNAscope (Advanced Cell Diagnostics) following the manufacturer's protocol (Masand et al., 2011). For each gene, a set of 40 specific probes ( $25 \mathrm{bp}$ in length in average) were synthesized that span $\sim 1 \mathrm{~kb}$ region in entirety with no base gaps in between. The probes were designed in pairs, of which each probe had a different oligonucleotide tail that contributed to one essential half of the binding site for a preamplifier. Each preamplifier could hybridize to 20 amplifiers, each of which could hybridize to 20 fluorescent label probes. For dual fluorescence in situ, each set of the probes uses different oligonucleotide tails, preamplifiers, amplifiers, and label probes that were labeled with unique fluorophores. In control experiments, brain sections were incubated with probes of DapB, a protein of Escherichia coli that is not expressed in mammalian cells, or probes against ubiquitin C, a protein that is ubiquitously expressed. As shown in supplemental Figure S3 (available at www.jneurosci.org as supplemental material), no signal was produced by the DapB probes, whereas the ubiquitin $C$ probes labeled all cells in brain sections. This demonstrated the specificity of the in situ method. Three to six views $(150 \mu \mathrm{m} \times 230 \mu \mathrm{m}$ per view) were randomly selected in each of layers II to VI (total $14-18$ views) and FISH-labeled cells were counted by using ImageJ software. The sequences for probe generation were as follows: type I NRG1, 31-444 of U02322 + 544 bp intron; type II NRG1, 37-514 of AF194993 + 432 bp intron; type III NRG1, 37-1179 of AF194438; GAD67, 974-1925 of M76177.1; VGLUT1, 532-1633 of U07609.1.

Electrophoretic mobility shift assay. Electrophoretic mobility shift assay (EMSA) was performed as described previously with modification (Kim et al., 2005). Briefly, His-CREB1 was purified by Ni-NTA (Qiagen), desalted by Centriprep (Millipore), and incubated in $20 \mu \mathrm{l}$ (final volume) of the DNA-binding buffer [10 mM HEPES, pH 7.9, $50 \mathrm{~mm} \mathrm{KCl,} 0.5 \mathrm{~mm}$ dithiothreitol, $5 \%$ glycerol and $0.1 \mu \mathrm{g}$ of poly(dI-dC) ] and $2.5 \mathrm{~nm}$ IRDye
700 end-labeled double-stranded oligonucleotide probes (Eurofins MWG Operon). After incubation at $30^{\circ} \mathrm{C}$ for $15 \mathrm{~min}$, the reaction mixture was resolved by $6 \%$ PAGE in $0.5 \times$ Tris-borate-EDTA buffer at $4^{\circ} \mathrm{C}$. IRDye-probes and associated complexes were visualized by Odyssey Infrared Imaging System (LI-COR). In some reactions, excessive unlabeled double-stranded oligonucleotides or anti-CREB antibody was included. The proximal CRE ( $\mathrm{p}-\mathrm{CRE}$ ) probe sequence was 5'CAGGT CCTTG CTCAC TGAAG CGTCA CCTCT CACTC CCCAG, where the CRE element was indicated in bold.

Statistical analysis. For multiple group comparisons, statistical differences were calculated by one-way ANOVA followed by paired Student's $t$ test. For data presentation, normalized values were averaged and presented as mean \pm SEM. Values of $p<0.05$ were considered statistically significant.

\section{Results}

\section{NRG1 isoform compositions of the} human cerebral cortex

There are six types of NRG1 in humans, each of which has a distinct N-terminal region (Steinthorsdottir et al., 2004; Mei and Xiong, 2008). Types I, II, IV, and V have an Ig domain before the EGF domain, whereas types III and VI do not (Fig. 1A). RT-qPCR was performed to characterize the composition of NRG1 isoforms in human brain and to determine whether it changes during development. Forward primers were designed based on type-specific sequences (Fig. 1A; supplemental Fig. S1 $A$, available at www.jneurosci.org as supplemental material). Reverse primers were against either the Ig (for types I, II, IV, and V) or EGF domain (for types III and VI). To ensure similar and high efficiency qPCR among different types, two additional criteria were used. First, primers were designed to have identical annealing temperatures (i.e., $60^{\circ} \mathrm{C}$ ) for all types of NRG1, including those for the gene $\beta$-actin. Second, the size of PCR products was kept to $<200 \mathrm{bp}$. Sequences of these primers are shown in supplemental Figure S1 A (available at www.jneurosci.org as supplemental material). Using human cerebral cortex cDNA as a template, PCR with type-specific primers generated products of predicted sizes (Fig. $1 B$ ). Finally, to measure the absolute mRNA copy number of a given isoform, each qPCR plate included three samples that contained known copy numbers (i.e., $10^{2}, 10^{4}$, and $10^{6}$ ) of isoformspecific templates, to generate a standard curve.

As shown in Figure 1, $C$ and $E$, all six types of NRG1 were detectable in the cerebral cortex of healthy human subjects at ages 13 and 60, in agreement with previous reports (Steinthorsdottir et al., 2004; Tan et al., 2007). We measured the mRNA copy number of each isoform per microgram of RNA. Unless otherwise indicated, "copies" throughout the text indicates mRNA copy numbers per microgram of total RNA. The most abundant type at age 13 was type III, accounting for $\sim 59 \%$ (with $3.39 \pm$ $0.11 \times 10^{5}$ copies $)$, followed by types II $(\sim 29 \%, 1.68 \pm 0.07 \times$ $10^{5}$ copies $), \mathrm{V}\left(\sim 7 \%, 3.96 \pm 0.17 \times 10^{4}\right.$ copies $)$, and I $(\sim 4 \%$, $2.45 \pm 0.15 \times 10^{4}$ copies $)$. Levels of types IV and VI were extremely low, accounting for $<1 \%$ of total NRG1 $(1.40 \pm 0.32 \times$ $10^{3}$ and $3.08 \pm 0.91 \times 10^{2}$ copies, respectively). During development or aging, the total copy concentration reduced by $\sim 29 \%$ from $5.73 \pm 0.10 \times 10^{5}$ copies in 13 -year-old cerebral cortex to 
$3.99 \pm 0.36 \times 10^{5}$ copies in 60 -year-old cerebral cortex. This resulted from reduction in all NRG1 isoforms. Nevertheless, type III remained the most dominant isoform representing $\sim 73 \%$ $\left(2.92 \pm 0.23 \times 10^{5}\right.$ copies $)$ of total NRG1. The increase in type III's representation appeared to be at the sacrifice of types II and $\mathrm{V}$ (reduced to $\sim 21 \%$ and $\sim 1 \%$, respectively). The composition of types I, IV, and VI showed no significant change although the copy numbers were reduced proportionally. These results demonstrate that the major NRG1 isoform in human cortex is type III, followed by types II and I; and the composition changes during development in particular for type $\mathrm{V}$.

\section{Distinct expression patterns of NRG1 isoforms during rat neural development}

Type I, II, and III are known to express in rodent brains (PinkasKramarski et al., 1994; Corfas et al., 1995; Lu et al., 1995; Chuah et al., 2000; Bovetti et al., 2006; Edwards and Bottenstein, 2006). However, whether the other, novel types exist in rodent brains remains unknown. Neither is known about relative levels of NRG1 isoforms during development. Similar strategies for human NRG1 primers were used to design primers of rat NRG1 types (Fig. 1A; supplemental Fig. S2A, available at www. jneurosci.org as supplemental material). Because information was not available on mRNA sequences of rodent type IV, V, and VI NRG1s, we aligned rat genome sequences to human mRNA sequences and identified putative, correspondent exons in rat. Forward primers against rat types IV, V, and VI were designed based on these sequences (supplemental Fig. S2 A, available at www.jneurosci.org as supplemental material). One additional pair of primers was designed against the EGF domain to detect all isoforms (Fig. 1A). As with studies of human NRG1 isoforms, PCR products were kept $<200 \mathrm{bp}$ and primers had identical annealing temperatures (i.e., $60^{\circ} \mathrm{C}$ ) for all types of NRG1, $\beta$-actin, and BDNF, except those of type IV, whose annealing temperature was $70^{\circ} \mathrm{C}$ to obtain specific bands. Because of this, we designed another pair of primers for $\beta$-actin (RT-b-2) with annealing temperature at $70^{\circ} \mathrm{C}$ (supplemental Fig. S2A, available at www. jneurosci.org as supplemental material). Using the cDNA of rat embryonic brain as template, PCR with type-specific primers generated products of predicted sizes (Fig. 2A). To make sure that the products were not artifacts amplified by PCR, they were subcloned into pGEX-T-easy vector (Promega) and verified by DNA sequencing (Fig. 2 B). Similar result was observed in mouse brain (data not shown). These indicate that six different types of NRG1 are expressed in rodent embryonic brains.

As in studies of human NRG1 isoforms, the absolute mRNA copy concentration of a given isoform was calculated based on isoformspecific standard curves generated on the same qPCR plate. As shown in Figure 3, $A$ and $B$, in E18 rat cerebral cortex, type II was the most abundant NRG1 isoform (with $1.28 \pm 0.06 \times 10^{6}$ copies), accounting for $46.66 \%$ of total NRG1 isoforms. Next abundant isoforms were types I and III (with $6.81 \pm 0.09 \times 10^{5}$ and $7.81 \pm 0.17 \times$ $10^{5}$ copies, respectively), accounting for $\sim 25 \%$ and $\sim 28 \%$, respectively. These three types account for $>99 \%$ of total NRG1s in the embryonic cortex. Among the remainder were types IV and V with about $5.57 \pm 1.27 \times 10^{2}$ and $3.89 \pm 0.85 \times 10^{3}$ copies, respectively. Type VI was the least abundant (with $<50$ copies) in embryonic cortex.

Interestingly, total NRG1 levels in the cortex at postnatal day 5 (P5), a critical period of neural development (Clancy et al., 2007), were increased by 7.7 -fold (to $2.12 \pm 0.12 \times 10^{7}$ copies). The increase occurred in all isoforms (Fig. $3 C$ ). Remarkably, type $\mathrm{V}$ increased by 718 -fold to $2.79 \pm 0.50 \times 10^{6}$ copies, which ac-
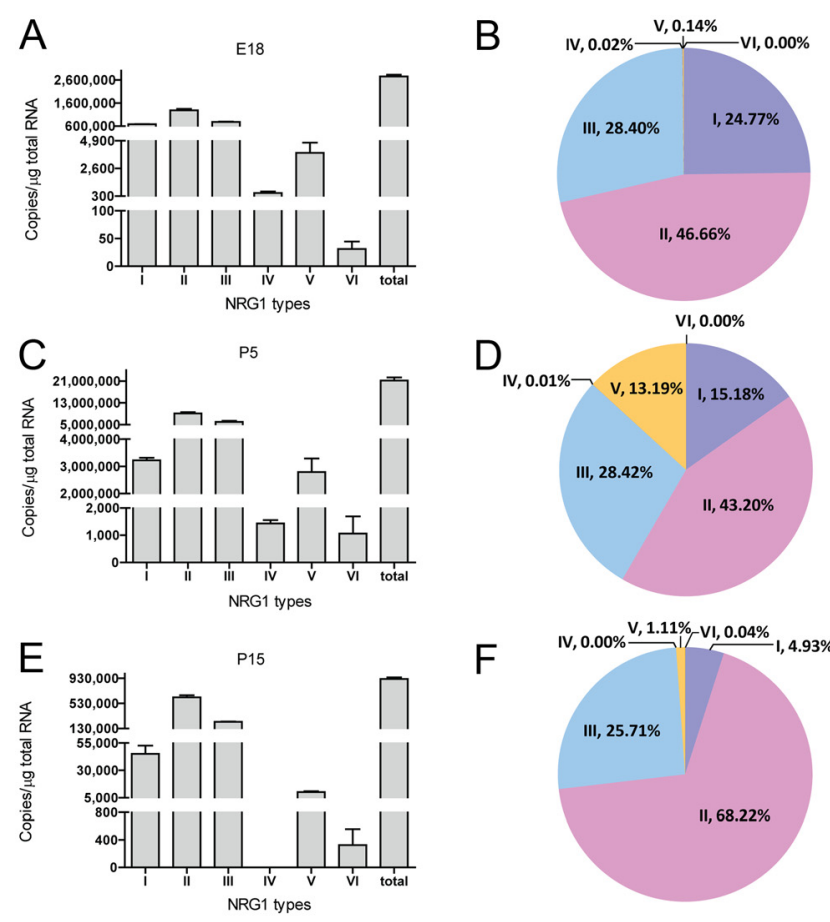

F

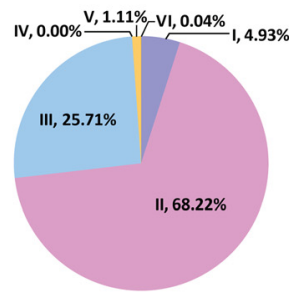

G

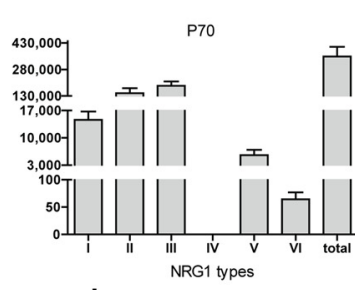

$\mathrm{H}$

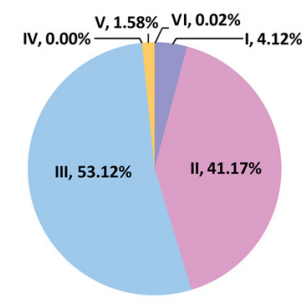

I

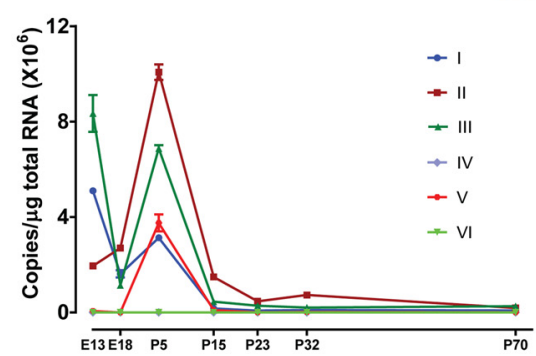

Figure 3. Development-dependent expression of NRG1 types. RT-qPCR was performed as described in Figure $1 A$ with the RNA templates of cerebral cortex of different age. $A$, Different expression levels of NRG1 types in E18 cerebral cortex. The copy numbers per microgram of total RNA of each type of NRG1 were $6.81 \pm 0.09 \times 10^{5}$ (type I), $1.28 \pm 0.06 \times 10^{6}$ (type II), $7.81 \pm 0.17 \times 10^{5}$ (type III), $557 \pm 127$ (type IV), $3890 \pm 850$ (type V), and $31 \pm 14$ (type VI), whereas that for total NRG1 was $2.75 \pm 0.08 \times 10^{6}$. B. Composition of NRG1 types in E18 cerebral cortex. C, Different expression levels of NRG1 types in P5 cerebral cortex. The copy numbers per microgram of total RNA of each type NRG1 were $3.22 \pm 0.10 \times 10^{6}$ (type I), $9.16 \pm 0.45 \times 10^{6}$ (type II), $6.03 \pm 0.40 \times 10^{6}$ (type III), $1.43 \pm 0.12 \times 10^{3}$ (type IV), $2.79 \pm 0.50 \times 10^{6}\left(\right.$ type V), and $1.06 \pm 0.63 \times 10^{3}$ (type VI), whereas that for total NRG1 was $2.12 \pm 0.12 \times 10^{7}$. D, Composition of NRG1 types in P5 cerebral cortex. E, Different expression levels of NRG1 types in P15 cerebral cortex. The copy numbers per microgram of total RNA of each type NRG1 were $4.51 \pm 0.75 \times 10^{4}$ (type I), $6.25 \pm 0.33 \times 10^{5}$ (type II), $2.35 \pm 0.06 \times$ $10^{5}$ (type III), 0 (undetectable, type IV), $1.02 \pm 0.08 \times 10^{4}$ (type V), and $3.26 \pm 2.32 \times 10^{2}$ type VI, whereas that for total NRG1 was $9.16 \pm 0.27 \times 10^{7} . F$, Composition of NRG1 types in P15 cerebral cortex. G, Different expression levels of NRG1 types in P70 cerebral cortex. The copy numbers per microgram of total RNA of each type NRG1 were $1.46 \pm 0.21 \times 10^{4}$ (type I), $1.46 \pm 0.28 \times 10^{5}$ (type II), $1.88 \pm 0.25 \times 10^{5}$ (type III), 0 (undetectable, type IV), $5.58 \pm$ $13.60 \times 10^{2}$ (type V), and $64 \pm 13$ (type IV), whereas that for total NRG1 was $3.54 \pm 0.55 \times$ $10^{7}$. H, Composition of NRG1 types in P70 cerebral cortex. I, Alteration of NRG1 types in developing cerebral cortex. 

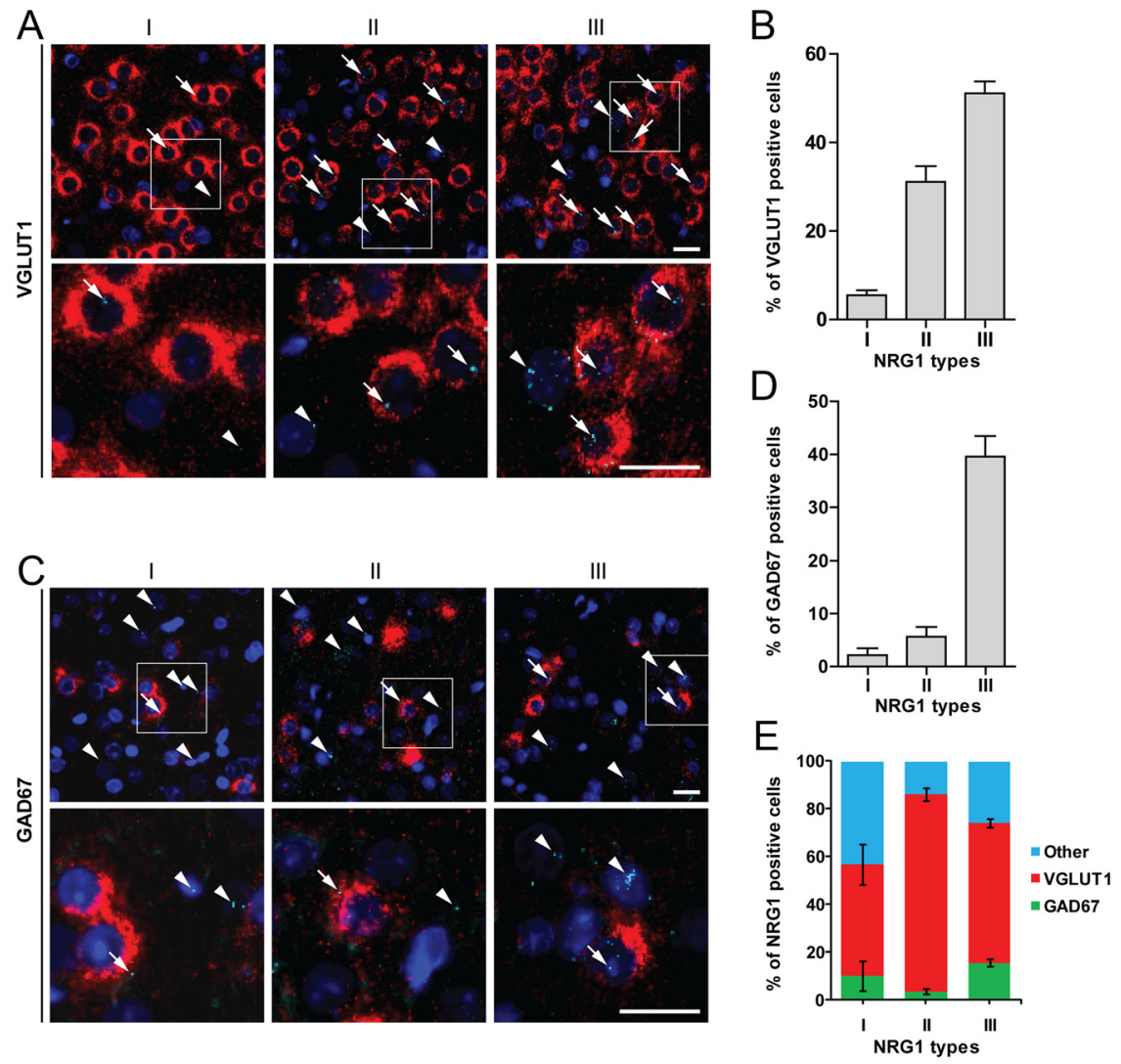

Figure 4. Expression of NRG1 isoforms in excitatory and inhibitory neurons and astrocytes. Dual FISH was performed to determine which cells in the cortex express NRG1 isoforms. $\boldsymbol{A}$, Representative images of dual FISH of VGLUT1 (red) and NRG1 isoforms (aqua). Regions in white rectangles in the upper panels were enlarged in lower panels. Arrowheads indicate cells expressing NRG1 isoforms, but not VGLUT1. Arrows indicate cells expressing both NRG1 isoforms and VGLUT1. Scale bar, $20 \mu \mathrm{m}$. $\boldsymbol{B}$, Percentage of VGLUT1-positive cells expressing NRG1 types I $(5.47 \pm 1.13 \%, n=18)$, II $(31.09 \pm 3.58 \%, n=18)$, or III $(51.10 \pm 2.71 \%, n=$ 14). C, Representative images of dual FISH of GAD67 (red) and NRG1 isoforms (aqua). Regions in white rectangles in the upper panels were enlarged in lower panels. Arrowheads indicate cells expressing NRG1 isoforms, but not GAD67. Arrows indicate cells expressing both NRG1 isoforms and GAD67. Scale bar, $20 \mu \mathrm{m}$. D, Percentage of GAD67-positive cells expressing NRG1 types I $(2.15 \pm 1.29 \%, n=18)$, II $(5.62 \pm 1.83 \%, n=18)$, or III $(39.56 \pm 3.91 \%, n=14)$. $\boldsymbol{E}$, Distribution of NRG1 isoforms in VGLUT1$(\mathrm{I}, 46.50 \pm 8.35 \%, n=18 ; \mathrm{Il}, 82.47 \pm 2.78 \%, n=18 ; \mathrm{III}, 58.61 \pm 1.87 \%, n=18)$ and GAD67- $(\mathrm{l}, 10.19 \pm 6.20 \%, n=18 ; \|$, $3.63 \pm 1.23 \%, n=18 ;$ III, $15.58 \pm 1.64 \%, n=14$ ) positive neurons.

counted for $\sim 13 \%$ of total NRG1. Type VI increased by 34 -fold, to $1.06 \pm 0.63 \times 10^{3}$ copies. Nevertheless, types II, III, and I remained to be most abundant, accounting for $\sim 43 \%, \sim 28 \%$, and $\sim 15 \%$, respectively (Fig. $3 D$ ). The total NRG1 levels reduced dramatically at P15, to $9.16 \pm 0.27 \times 10^{5}$ copies and remained relatively low afterward (Fig. $3 E, I$ ). Most noticeable changes were for types I (from $\sim 15 \%$ to $\sim 5 \%$ ), $\mathrm{V}$ (from $\sim 13 \%$ to $\sim 1 \%$ ), and IV (from detectable to undetectable) (Fig. $3 F$ ). Type IV remained undetectable afterward and in adult. This observation was in agreement with a recent report that human type IV NRG1 mainly expresses in fetal stage (Tan et al., 2007).

These results could suggest unique functions of NRG1 isoforms during development and underlying regulatory mechanisms. The developmental changes alter the composition of NRG1 signaling contributed by each isoform in adult cortex. At P70, the most abundant NRG1 isoforms are types III and II, accounting for $\sim 53 \%$ and $\sim 41 \%$, respectively. Followed by type I ( $\sim 25 \%)$, type V $(\sim 2 \%)$, and type VI $(<1 \%)$. Type IV is undetectable (Fig. 3G,H). Similar developmental expression patterns were observed for NRG1 isoform expressions in the hippocampus (data not shown). At E13, type I and III NRG1 were expressed at higher levels than at E18, suggesting a role of these two isoforms in early development.
Expression of NRG1 isoforms in neurons and astrocytes

Brain expression of NRG1 isoforms has been studied by in situ hybridization (Pinkas-Kramarski et al., 1994; Corfas et al., 1995; Eilam et al., 1998; Kerber et al., 2003; Flames et al., 2004; Woo et al., 2007). However, no information is available regarding cellular expression pattern of NRG1 isoforms. To determine in which cells NRG1 isoforms are expressed, we performed fluorescent in situ hybridization (FISH) by using RNAscope (Advanced Cell Diagnostics). The characterized type-specific sequences of type IV, $\mathrm{V}$, and VI are $<100 \mathrm{bp}$, shorter than the optimal length of probes for in situ hybridization. Therefore, we focused on expression of types I, II, and III in the cortical region. As shown in Figure 4A, these isoforms were detectable in neurons labeled by VGLUT1, a marker of excitatory neurons (Bellocchio et al., 2000). Quantitative analysis indicated that $\sim 51 \%$ of VGLUT1-positive neurons were positive for type III, $\sim 31 \%$ for type II, and $\sim 5 \%$ for type I (Fig. $4 B$ ). Notice that NRG1 signals were also present in cells that were not positive for VGLUT1, suggesting that they may be expressed in other neurons or cells. To address this question, dual FISH was done with probes for NRG1 isoforms and GAD67, a marker of GABAergic interneurons (Esclapez et al., 1993). Indeed, NRG1 isoforms costained with GAD67: 40\% of GAD67positive neurons were positive for type III, $\sim 6 \%$ for type II, and $\sim 2 \%$ for type I (Fig. $4 C, D)$. Interestingly, of type I-positive cells, $\sim 10 \%$ were positive for GAD67 and $\sim 46 \%$ for VGLUT1, leaving $\sim 43 \%$ of cells negative for either of the markers (Fig. $4 E$ ). Similarly, $\sim 14 \%$ of type II-positive and $\sim 26 \%$ of type III-positive cells were negative for either VGLUT1 or GAD67 (Fig. 4E). These results suggested that NRG1 isoforms may be expressed in cells "other" than excitatory or inhibitory neurons. We speculated that astrocytes may express NRG1, and tested this notion by RT-qPCR analysis of cultured rat astrocytes. As shown in Figure 6G, various NRG1 isoforms were detectable in astrocytes, where the composition was $\sim 83 \%$ for type I, $\sim 13 \%$ for type III, $\sim 4 \%$ for type II, and remainder isoforms $<1 \%$. This result is in agreement with the report that NRG1 is present in astrocytes (Kerber et al., 2003).

\section{Neuronal activity differently regulates NRG1 expression}

Neuronal activity was shown to increase NRG1 expression (Eilam et al., 1998), where the NRG1 primers would detect isoforms containing the Ig and EGF domains, which include types I, II, IV, and V NRG1. It remains unknown which type(s) of NRG1 are regulated by neuronal activity. To determine which types are targets of neuronal activity, epileptic seizures were induced in adult rat brain by kainic acid injection (10 mg/kg, i.p.) (Sperk et al., 1983). Under our conditions, seizures began to develop within $1 \mathrm{~h}$ of injection and continued for at least $5 \mathrm{~h}$. Kainic acid-treated rats and controls (injected 
with saline) were killed $4 \mathrm{~h}$ after treatment and total RNAs were isolated for RT-qPCR as described above. Two control gene probes were included: $\beta$-actin and BDNF. Kainic acid treatment had no effect on $\beta$-actin expression in the cortex, but increased BDNF levels, in agreement with previous observations (Zafra et al., 1990; Metsis et al., 1993; Timmusk et al., 1993; Castrén et al., 1998). These results indicate successful establishment of the method to increase neuronal activity in rats. As shown in Figure 5, neuronal activity has distinct effects on expression of NRG1 isoforms. While it had no effect on levels of types III, V, or VI, levels of types I and II were increased to 8.9- and 1.9-fold above basal in the cortex of treated animals. Type IV remained undetectable in kainic acid-treated brain samples (data not shown). Similar regulation pattern was observed for NRG1 isoform expression in the hippocampus (data not shown).

To better investigate mechanisms, we determined whether the regulation of NRG1 isoform expression could occur in cultured neurons. To this end, we cultured E18 cortical neurons for 3-12 DIV and treated them with or without $50 \mathrm{~mm} \mathrm{KCl}$ for $6 \mathrm{~h}$. This treatment depolarizes neurons and has been shown to increase expression of BDNF (Shieh et al., 1998; Tao et al., 1998; Hong et al., 2008). Total RNAs were extracted and transcribed to CDNAs as described in Materials and Methods and levels of NRG1 were quantified by RTqPCR as described above. In untreated neurons, major types are types I, II, and III at DIV3, DIV9, and DIV12. Interestingly, type V increased significantly over time in cultured neurons $(0.28 \%$ at DIV3, 2.3\% at DIV9, and 12\% at DIV12) (Fig. 6; supplemental Fig. S6, available at www.jneurosci.org as supplemental material). Developmental change in expression was also observed in other types (supplemental Fig. S6, available at www.jneurosci.org as supplemental material). $\mathrm{KCl}$ treatment consistently increased levels of types I and IV at three different DIVs. Its effect on types III and VI appeared to be age dependent (increased only at DIV3 and DIV12, respectively). For reasons that are not understood, type II was not increased in $\mathrm{KCl}$-treated neurons although elevated in rats with induced seizure. We have also treated neurons briefly with $100 \mu \mathrm{M}$ KA that also activates neurons (Murphy and Miller, 1989), and found that this treatment increased levels of types I and IV, but not other isoforms (supplemental Fig. S4, available at www.jneurosci.org as supplemental material). Together with in vivo studies, these results indicate that neuronal expression of NRG1 isoforms is differentially regulated by activity. $\mathrm{KCl}$ treatment (for $6 \mathrm{~h}$ ) increased levels of type I, but not other types, of NRG1 in astrocytes (Fig. 6H). The result suggests that the increase in type I NRG1 in vivo may be contributed in part by increase in astrocytes. NRG1 joins a list of trophic factors whose expression in astrocytes is regulated by KCl-induced depolarization (Chang et al., 2001; Wu et al., 2004).

\section{Identification of cis-elements essential for neuronal activity regulation}

We investigated mechanisms by which neuronal activity regulates expression of NRG1 isoforms. To this end, we focused on types I and IV because their expression is altered in the brain of schizophrenia patients (Hashimoto et al., 2004; Law et al., 2006). Series of firefly luciferase constructs were generated that contained different lengths of 5'UTR and were cotransfected with the control vector pRL-TK into SH-SY5Y human neuroblastoma cells. Twelve hours later, cells were stimulated with $50 \mathrm{~mm} \mathrm{KCl}$ for $12 \mathrm{~h}$ and assayed for both firefly and Renilla luciferases. NRG1 reporter activity was normalized by Renilla luciferase activity. We were able to narrow neuronal activityresponsible cis-elements within 441 bp 5'UTR for type INRG1 (supplemental Fig. S5A, available at www.jneurosci.org as supplemental material). Within this region are two putative cis-elements: one for Egr-1 and another for NFAT-1, which have been implicated in neu-

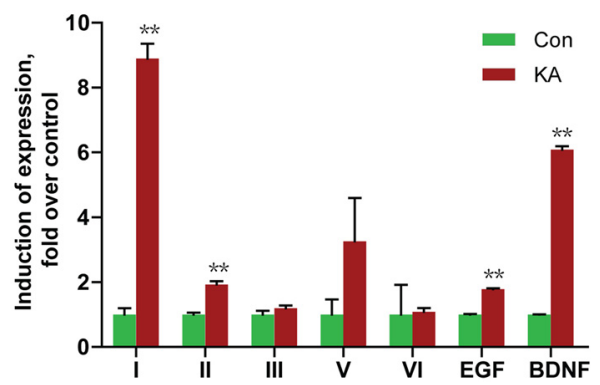

Figure 5. Increased expression of types I and II NRG1 in the cerebral cortex of KA-treated rats. Rats were injected with $10 \mathrm{mg} / \mathrm{ml} \mathrm{KA}$ to induce seizure and killed $4 \mathrm{~h}$ after injection. Total RNA were subjected to RT-qPCR. NRG1 types were first normalized by $\beta$-actin whose levels were revealed in same reactions and then normalized by control. ${ }^{* *} p<0.01$.
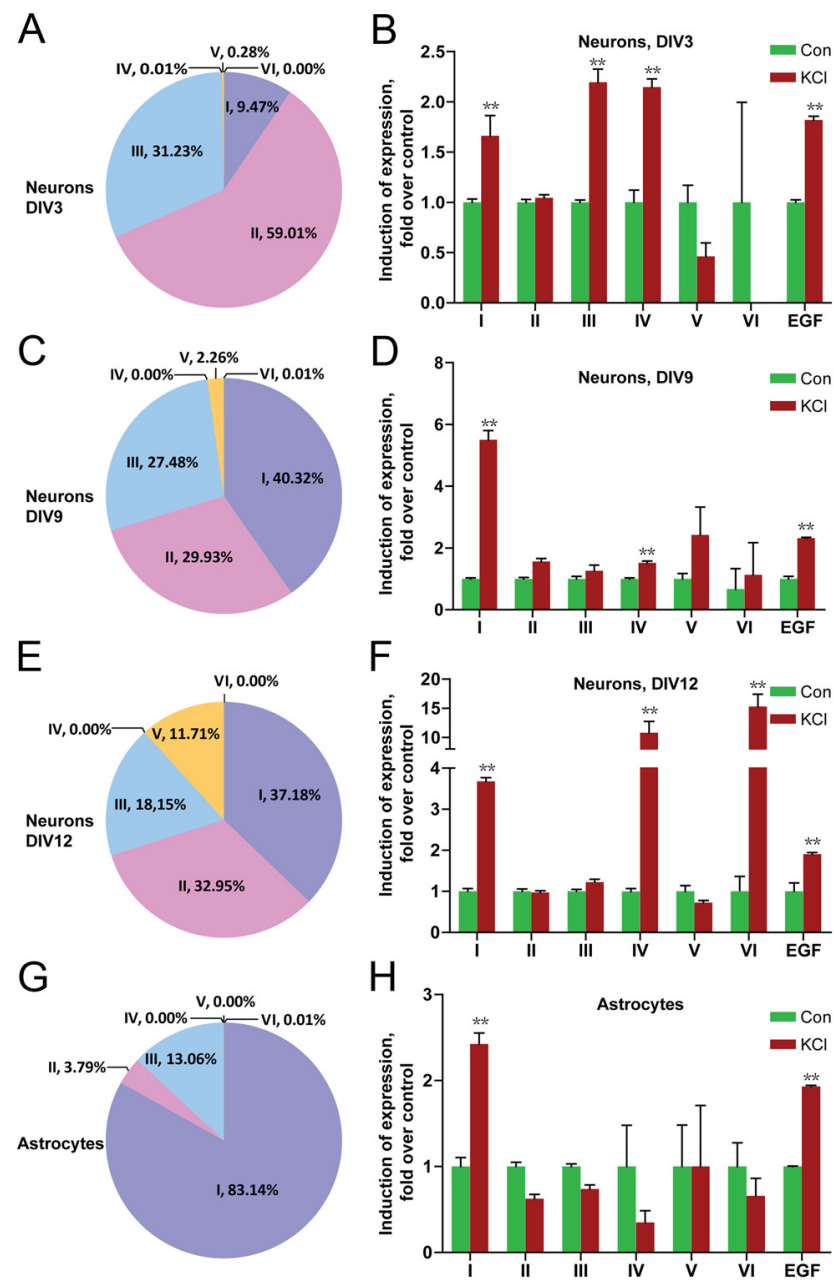

Figure 6. Differential regulation of NRG1 type expression in cultured neurons and astrocytes by $\mathrm{KCl}$ treatment. Total RNAs were isolated from control or $\mathrm{KCl}(50 \mathrm{~mm}, 6 \mathrm{~h})$-treated cortical neurons $(\boldsymbol{A}-\boldsymbol{F}$, indicated ages) and astrocytes $(\boldsymbol{G}, \boldsymbol{H})$, and subjected to RT-qPCR. NRG1 types were first normalized by $\beta$-actin, whose levels were revealed in the same reactions and then normalized by control. ${ }^{* *} p<0.01$.

ronal activity-dependent gene regulation (Asai et al., 2004; Knapska and Kaczmarek, 2004). However, their mutation on 2.9 kbp 5'UTR had no effect on response to neuronal activity (supplemental Fig. $\mathrm{S} 5 B, C$, available at www.jneurosci.org as supplemental material), indicating that they are dispensable. Attempts to identify relevant cis-elements were not successful because deletion or mutation of 441 bp 5'UTR significantly reduced basal promoter activity. 


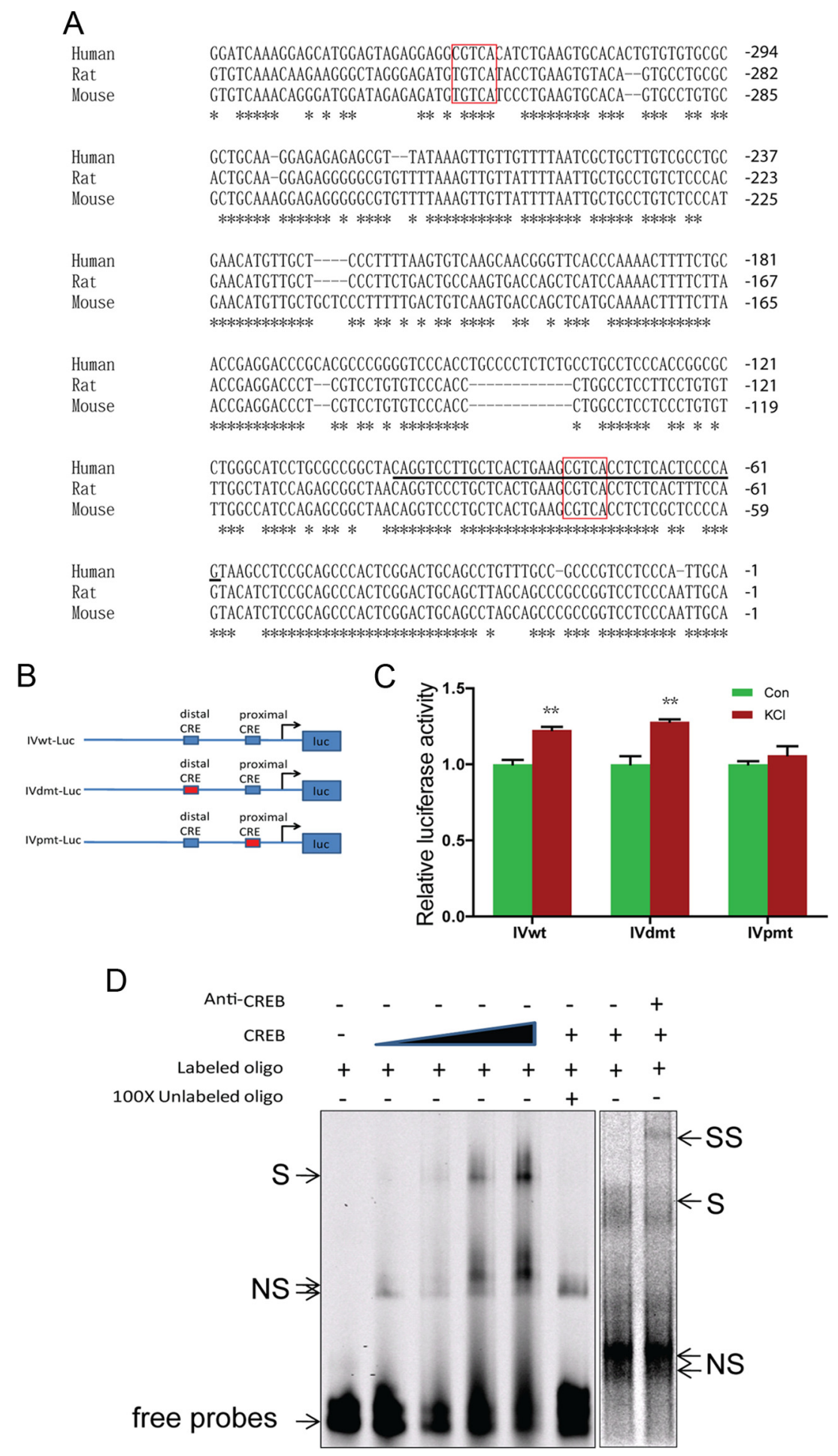

Figure 7. CRE cis-element is critical for activity-dependent regulation of type IV NRG1. $A$, Sequence comparison of type I5' UTRs of human, rat, and mouse. Distal and proximal CRE sites were highlighted in red rectangles. *Conserved nucleotides. Underlined sequence included $20 \mathrm{bp}$ upstream and $15 \mathrm{bp}$ downstream of CRE sites were used for EMSA. $\boldsymbol{B}$, Diagram of luciferase reporter constructs. C, The proximal CRE cis-element was necessary for activity-dependent increase of type IV expression. SH-SY5Y cells were cotransfected with indicated reporters and pRL-TK. Twelve hours after transfection, cells were treated with vehicle or $50 \mathrm{~mm}$ $\mathrm{KCl}$ for $12 \mathrm{~h}$. Luciferase activity was measured as described in Materials and Methods. ${ }^{* *} p<0.01 . \boldsymbol{D}$, Interaction between proximal CRE cis-element and CREB. Double-stranded oligonucleotides containing the proximal CRE of human type IV promoter (shown in Fig. $6 \mathrm{~A}$ ) were $5^{\prime}$ end-labeled with IRDye 700 and incubated with recombinant CREB1 for $15 \mathrm{~min}$ at $30^{\circ} \mathrm{C}$. In some experiments, $200 \times$ unlabeled oligonucleotides or anti-CREB antibody were included in the reaction. The reaction mixture was resolved on $4 \%$ nondenaturing polyacrylamide gel. S, Shift band; SS, super shift; NS, nonspecific band.
DNA sequence analysis of type IV 5'UTR revealed two putative CRE elements: proximal $(-73$ to -77$)$ and distal $(-319$ to -323), both with characteristic consensus sequence "CGTCA" (Fig. 7A). Notice that the proximal CRE and its surrounding nucleotides are conserved among different species, including humans, rats, and mice. On the other hand, the distal CRE site exists only in human, not in rodents. CRE elements interact with CREB, a transcription factor known to play a critical role in neuronal activity-induced gene expression (Sheng et al., 1991; Tao et al., 1998; Redmond et al., 2002). To determine whether the CRE elements are necessary for neuronal activityinduction of type IV expression, we generated a luciferase reporter construct that contained $1.6 \mathrm{~kb}$ human type IV promoter $(-1560$ to +91$)$ (Tan et al., 2007) and two mutants where either the proximal or distal CRE element was mutated to "TTTAA" (IVpmt-Luc and IVdmt-Luc, respectively) (Fig. 7B). They were transfected into human neuroblastoma SH-SY5Y cells and luciferase activity was measured in control and $\mathrm{KCl}$-treated neurons. As shown in Figure $7 C$, mutation of the proximal CRE prevented type IV 5'UTR from responding to neuronal activity stimulation, whereas mutation of the distal CRE had little effect. These results suggested an important role of the proximal CRE for neural activitydependent regulation.

Next, we determined whether the proximal CRE was able to bind to CREB by EMSA. Double-stranded oligonucleotide probes were synthesized containing the proximal CRE with 20 bp upstream and 15 bp downstream flanking sequence (indicated by black line in Fig. 7A), 5' end-labeled with IRDye 700, and incubated with purified recombinant CREB protein (Kim et al., 2005). As shown in Figure $7 D$, the addition of recombinant CREB caused a delay in migration of labeled proximal CRE probes in a dose-dependent manner, indicating that CREB could bind to the proximal CRE. The interaction was specific because, first, it was diminished in the presence of excessive unlabeled probes. Second, the addition of specific anti-CREB antibodies caused a supershift of the probe-CREB complex. Together, these results suggest that the proximal CRE binds to CREB to promote type IV expression in response to neuronal activation. Intriguingly, the schizophrenia risk allele SNP8NRG243177 (rs6994992) is localized in the 5'UTR region of the type IV NRG1 (Stefansson et al., 2002). It is associated with reduced activation of frontal and temporal lobe regions and increased development of psychotic symptoms and decreased 
premorbid IQ (Hall et al., 2006). It was shown to reduce the basal activity of the type IV NRG1 promoter (Tan et al., 2007). The C-to-T mutation had no effect on activitymediated induction of the type IV promoter (Fig. 8)

\section{Discussion}

Major findings of this study are as follows. First, each of the six types of NRG1 has a distinct expression pattern in the brain at different ages, resulting in a change in NRG1 isoform composition. In humans and rats the most dominant is type III and II followed by either type I or V, while type IV and VI are least abundant $(<1 \%$ of total NRG1). Second, levels of NRG1 isoforms are higher in brains of E13 and P5 rats, suggesting roles in early neural development and in the neonatal critical period. Third, at the cellular level, the majority of NRG1 isoforms (types I, II, and III) are expressed in neurons coexpressing VGLUT1, but they are also present in GAD67-positive neurons and astrocytes. Fourth, expression of each NRG1 isoform is distinctly regulated by neuronal activity. Neuronal activity regulation of type IV expression requires a CRE cis-element in the $5^{\prime} \mathrm{UTR}$ that bind to CREB.

The most abundant NRG1 isoforms in embryonic brains are types I, II, and III, in agreement with previous observations that these isoforms play roles in neural development. For example, type I NRG1 regulates the generation of neural crest-derived neurons in cranial ganglia (Meyer et al., 1997) and long-range attraction of migrating interneurons (Flames et al., 2004). Type III NRG1 could act as a short-range attractant for migrating interneurons in the CNS (Flames et al., 2004) and is critical for development of neural crest-derived Schwann cells (Meyer et al., 1997; Wolpowitz et al., 2000). Type II NRG1 has been implicated in the development of Schwann cells and myelination and ensheathment of peripheral nerves (Marchionni et al., 1993; Trachtenberg and Thompson, 1996) and protection of dopaminergic neurons (Zhang et al., 2004). Interestingly, NRG1 isoforms in rat brains increase to highest levels (7.7-fold of levels of E18) at P5, when an epoch of plasticity occurs during the so-called critical period (P0P5) for rat primary somatosensory cortex (Rice and Van der Loos, 1977; Schlaggar and O'Leary, 1993). In particular, type V levels were increased transiently by $>700$-fold, from representing $<1 \%$ of total NRG1 at E18 to $\sim 13 \%$ at P5. Notice that type V is expressed at higher levels in 13-year-old human brain. However, the function of type $\mathrm{V}$ remains unclear as it contains only 16 type-specific $\mathrm{N}$-terminal amino acids that are predicted by cDNA. This short type-specific sequence made it difficult to determine which neurons or cells express type V NRG1. The novel type V exon is $\sim 600 \mathrm{~kb}$ downstream of type II and IV exons, and $\sim 300 \mathrm{~kb}$ upstream of type I exon (Steinthorsdottir et al., 2004). So far, no disease-associated SNP has been identified around this exon. Nevertheless, the unique expression pattern of type V NRG1 suggests a potential role in plasticity in the critical period that warrants further investigation.
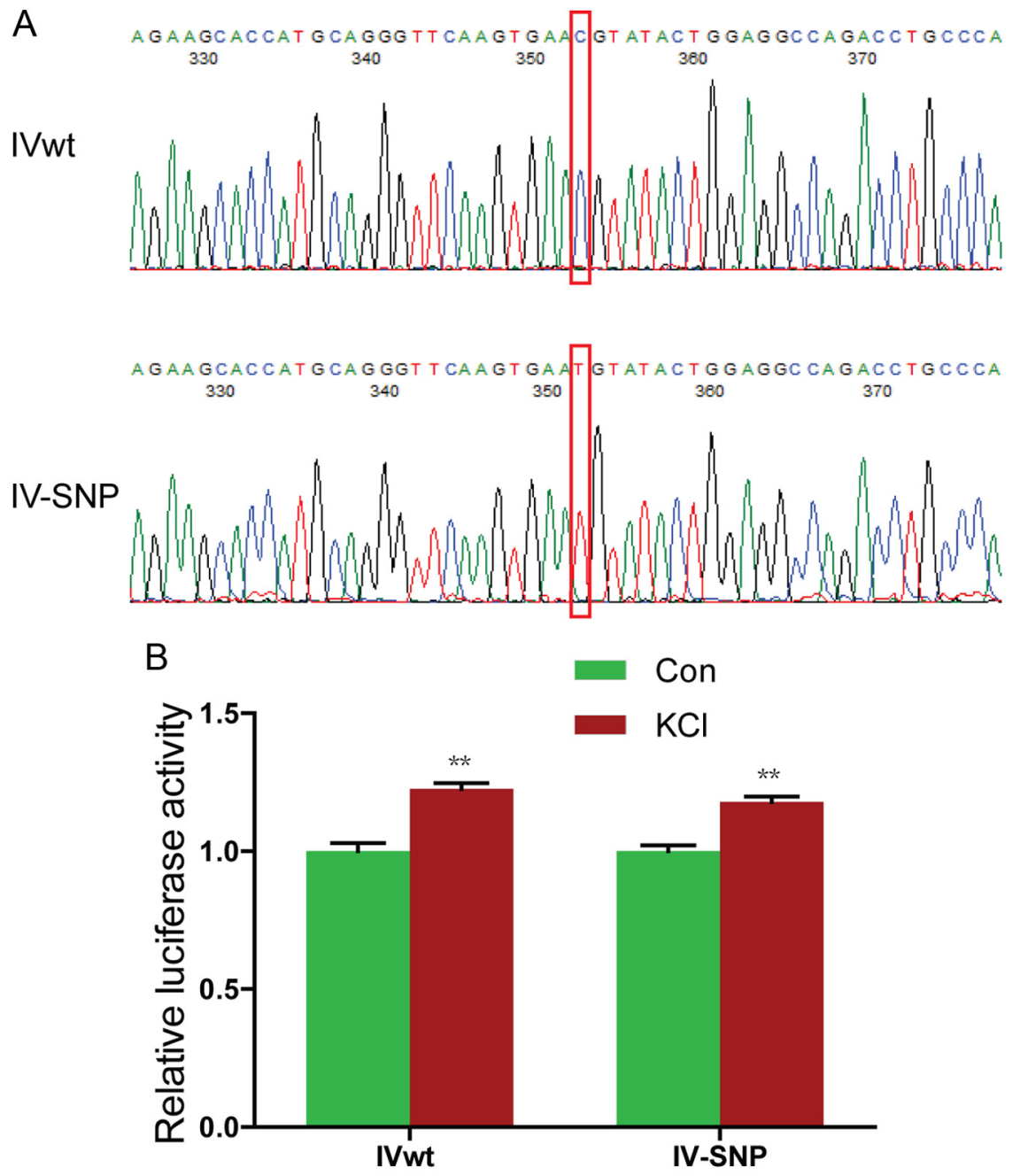

Figure 8. SNP8NRG243177 (rs6994992) has no effect on the regulation by neuronal activity. $A$, DNA sequences of IVwt-Luc and IV-SNP. The C-to-T mutation was indicated by red rectangles. The backbone of the Luc constructs was described in Figure 7B. $\boldsymbol{B}$, No effect of SNP8NRG243177 T allele on KCl-induced type IV NRG1 promoter activity. ${ }^{* *} p<0.01$.

In human and rat adult brain, the compositions of NRG1 are very similar with two dominant types (type III representing $\sim 73 \%$ in human and $\sim 53 \%$ in rat; and type II, representing $\sim 21 \%$ in human and $\sim 41 \%$ in rat). NRG1 isoforms (type III, II, and I) are expressed in both VGLUT1- and GAD67-positive neurons, as well as astrocytes. Whether one or more isoforms are expressed in a single neuron or cell awaits further study. Target of NRG1 in neurotransmission and synaptic plasticity include GABAergic interneurons (Woo et al., 2007; Chen et al., 2010; Wen et al., 2010; Ting et al., 2011), glutamatergic neurons ( $\mathrm{Gu}$ et al., 2005; Kwon et al., 2005; Li et al., 2007), and dopaminergic neurons (Zhang et al., 2004; Kwon et al., 2008; Zheng et al., 2009). Therefore, NRG1 may function both autonomously and non-autonomously.

Neuronal activity regulates expression of genes that are critical for neural development and/or synaptic plasticity (West et al., 2002; Flavell and Greenberg, 2008). NRG1 expression was shown previously to be regulated by increased neuronal activity (Eilam et al., 1998). Here we show that neuronal activity differentially regulates the expression of NRG1 isoforms. Increased neuronal activity appears to have no effect on levels of types III and II, the two major isoforms that represent $94 \%$ in adult brain. In contrast, type I is increased by 8.9 -fold in vivo after epileptic seizure 
and by 3.7-fold in cultured neurons after depolarization. Although type II was elevated by a modest 1.9 -fold in vivo, its level remains unchanged in neurons after depolarization, suggesting that the increase may be a secondary effect. Type IV mRNA was not detectable in adult naive or kainic acid-treated brain, but was increased by 10.8 -fold in $\mathrm{KCl}$-treated neurons in culture. Intriguingly, its response to neuronal activation appears to require a CRE cis-element that binds to CREB, a transcription factor that has been implicated in synaptic plasticity (Qiu and Ghosh, 2008; Alberini, 2009; Benito and Barco, 2010). For example, it is critical for activity-dependent BDNF expression (Tao et al., 1998; Hong et al., 2008). Noticeably, in astrocytes, the expression of type I, the major type that is present in these cells, is also increased in response to $\mathrm{KCl}$ treatment. These observations indicate that brain activity would change the composition of NRG1 isoforms in different regions and different cells, and thus alter NRG1 function under physiological condition and pathological conditions including stroke and epilepsy.

Schizophrenia is a debilitating mental disorder that affects $1 \%$ of general population (Harrison and Weinberger, 2005; Frankland et al., 2008). NRG1 has been identified as a susceptibility gene of schizophrenia in various populations (Stefansson et al., 2002; Yang et al., 2003; Mei and Xiong, 2008). Most of the schizophrenia-associated SNPs are localized to the 5' and $3^{\prime}$ regulatory regions of the NRG1 gene (Stefansson et al., 2002, 2003; Yang et al., 2003; Corvin et al., 2004; Li et al., 2004; Zhao et al., 2004; Petryshen et al., 2005; Harrison and Law, 2006; Lachman et al., 2006; Munafò et al., 2006; Benzel et al., 2007). The 5'SNPs may regulate NRG1 expression in schizophrenic patients (Law et al., 2006; Silberberg et al., 2006). Accordingly, types I, II, and IV are at higher levels in the prefrontal cortex and/or hippocampus of schizophrenic patients (Hashimoto et al., 2004; Law et al., 2006; Chong et al., 2008; Parlapani et al., 2010), with increased NRG1 signaling (Hahn et al., 2006), whereas type I NRG1 was reduced in some patients (Parlapani et al., 2010). The schizophrenia-associated allele SNP8NRG243177, located in the 5'UTR of type IV NRG1, appeared to have no effect on the induction by neuronal activity. Exactly how these SNPs regulate NRG1 expression remains unclear.

\section{References}

Alberini CM (2009) Transcription factors in long-term memory and synaptic plasticity. Physiol Rev 89:121-145.

Anton ES, Marchionni MA, Lee KF, Rakic P (1997) Role of GGF/neuregulin signaling in interactions between migrating neurons and radial glia in the developing cerebral cortex. Development 124:3501-3510.

Asai M, Iwasaki Y, Yoshida M, Mutsuga-Nakayama N, Arima H, Ito M, Takano K, Oiso Y (2004) Nuclear factor of activated T cells (NFAT) is involved in the depolarization-induced activation of growth hormonereleasing hormone gene transcription in vitro. Mol Endocrinol 18:3011-3019.

Backx L, Ceulemans B, Vermeesch JR, Devriendt K, Van Esch H (2009) Early myoclonic encephalopathy caused by a disruption of the neuregulin-1 receptor ErbB4. Eur J Hum Genet 17:378-382.

Bellocchio EE, Reimer RJ, Fremeau RT Jr, Edwards RH (2000) Uptake of glutamate into synaptic vesicles by an inorganic phosphate transporter. Science 289:957-960.

Benito E, Barco A (2010) CREB's control of intrinsic and synaptic plasticity: implications for CREB-dependent memory models. Trends Neurosci 33:230-240.

Benzel I, Bansal A, Browning BL, Galwey NW, Maycox PR, McGinnis R, Smart D, St Clair D, Yates P, Purvis I (2007) Interactions among genes in the ErbB-Neuregulin signalling network are associated with increased susceptibility to schizophrenia. Behav Brain Funct 3:31.

Bermingham-McDonogh O, McCabe KL, Reh TA (1996) Effects of GGF/ neuregulins on neuronal survival and neurite outgrowth correlate with
erbB2/neu expression in developing rat retina. Development 122: $1427-1438$.

Bjarnadottir M, Misner DL, Haverfield-Gross S, Bruun S, Helgason VG, Stefansson H, Sigmundsson A, Firth DR, Nielsen B, Stefansdottir R, Novak TJ, Stefansson K, Gurney ME, Andresson T (2007) Neuregulin1 (NRG1) signaling through Fyn modulates NMDA receptor phosphorylation: differential synaptic function in NRG1+/- knock-outs compared with wild-type mice. J Neurosci 27:4519-4529.

Bovetti S, De Marchis S, Gambarotta G, Fasolo A, Perroteau I, Puche AC, Bovolin P (2006) Differential expression of neuregulins and their receptors in the olfactory bulb layers of the developing mouse. Brain Res 1077:37-47.

Castrén E, Berninger B, Leingärtner A, Lindholm D (1998) Regulation of brain-derived neurotrophic factor mRNA levels in hippocampus by neuronal activity. Prog Brain Res 117:57-64.

Chang HY, Hua LL, Morgan A, Lee SC (2001) Inhibition of astrocyte TNFalpha expression by extracellular potassium. Brain Res 888:176-179.

Chen YJ, Zhang M, Yin DM, Wen L, Ting A, Wang P, Lu YS, Zhu XH, Li SJ, Wu CY, Wang XM, Lai C, Xiong WC, Mei L, Gao TM (2010) ErbB4 in parvalbumin-positive interneurons is critical for neuregulin 1 regulation of long-term potentiation. Proc Natl Acad Sci U S A 107:21818-21823.

Chong VZ, Thompson M, Beltaifa S, Webster MJ, Law AJ, Weickert CS (2008) Elevated neuregulin-1 and ErbB4 protein in the prefrontal cortex of schizophrenic patients. Schizophr Res 100:270-280.

Chuah MI, Cossins J, Woodhall E, Tennent R, Nash G, West AK (2000) Glial growth factor 2 induces proliferation and structural changes in ensheathing cells. Brain Res 857:265-274.

Clancy B, Finlay BL, Darlington RB, Anand KJ (2007) Extrapolating brain development from experimental species to humans. Neurotoxicology 28:931-937.

Corfas G, Rosen KM, Aratake H, Krauss R, Fischbach GD (1995) Differential expression of ARIA isoforms in the rat brain. Neuron 14:103-115.

Corvin AP, Morris DW, McGhee K, Schwaiger S, Scully P, Quinn J, Meagher D, Clair DS, Waddington JL, Gill M (2004) Confirmation and refinement of an 'at-risk' haplotype for schizophrenia suggests the EST cluster, Hs. 97362 , as a potential susceptibility gene at the Neuregulin-1 locus. Mol Psychiatry 9:208-213.

Edwards JM, Bottenstein JE (2006) Neuregulin 1 growth factors regulate proliferation but not apoptosis of a CNS neuronal progenitor cell line. Brain Res 1108:63-75.

Eilam R, Pinkas-Kramarski R, Ratzkin BJ, Segal M, Yarden Y (1998) Activity-dependent regulation of Neu differentiation factor/neuregulin expression in rat brain. Proc Natl Acad Sci U S A 95:1888-1893.

Esclapez M, Tillakaratne NJ, Tobin AJ, Houser CR (1993) Comparative localization of mRNAs encoding two forms of glutamic acid decarboxylase with nonradioactive in situ hybridization methods. J Comp Neurol 331:339-362.

Falls DL (2003) Neuregulins: functions, forms, and signaling strategies. Exp Cell Res 284:14-30.

Fazzari P, Paternain AV, Valiente M, Pla R, Luján R, Lloyd K, Lerma J, Marín O, Rico B (2010) Control of cortical GABA circuitry development by Nrg1 and ErbB4 signalling. Nature 464:1376-1380.

Fischbach GD, Rosen KM (1997) ARIA: a neuromuscular junction neuregulin. Annu Rev Neurosci 20:429-458.

Flames N, Long JE, Garratt AN, Fischer TM, Gassmann M, Birchmeier C, Lai C, Rubenstein JL, Marín O (2004) Short- and long-range attraction of cortical GABAergic interneurons by neuregulin-1. Neuron 44:251-261.

Flavell SW, Greenberg ME (2008) Signaling mechanisms linking neuronal activity to gene expression and plasticity of the nervous system. Annu Rev Neurosci 31:563-590.

Frankland PW, Sakaguchi M, Arruda-Carvalho M (2008) Starting at the endophenotype: a role for alpha-CaMKII in schizophrenia? Mol Brain 1:5.

Gerlai R, Pisacane P, Erickson S (2000) Heregulin, but not ErbB2 or ErbB3, heterozygous mutant mice exhibit hyperactivity in multiple behavioral tasks. Behav Brain Res 109:219-227.

Go RC, Perry RT, Wiener H, Bassett SS, Blacker D, Devlin B, Sweet RA (2005) Neuregulin-1 polymorphism in late onset Alzheimer's disease families with psychoses. Am J Med Genet B Neuropsychiatr Genet 139B:28-32.

Goes FS, Sanders LL, Potash JB (2008) The genetics of psychotic bipolar disorder. Curr Psychiatry Rep 10:178-189. 
Gu Z, Jiang Q, Fu AK, Ip NY, Yan Z (2005) Regulation of NMDA receptors by neuregulin signaling in prefrontal cortex. J Neurosci 25:4974-4984.

Hahn CG, Wang HY, Cho DS, Talbot K, Gur RE, Berrettini WH, Bakshi K, Kamins J, Borgmann-Winter KE, Siegel SJ, Gallop RJ, Arnold SE (2006) Altered neuregulin 1-erbB4 signaling contributes to NMDA receptor hypofunction in schizophrenia. Nat Med 12:824-828.

Hall J, Whalley HC, Job DE, Baig BJ, McIntosh AM, Evans KL, Thomson PA, Porteous DJ, Cunningham-Owens DG, Johnstone EC, Lawrie SM (2006) A neuregulin 1 variant associated with abnormal cortical function and psychotic symptoms. Nat Neurosci 9:1477-1478.

Harrison PJ, Law AJ (2006) Neuregulin 1 and schizophrenia: genetics, gene expression, and neurobiology. Biol Psychiatry 60:132-140.

Harrison PJ, Weinberger DR (2005) Schizophrenia genes, gene expression, and neuropathology: on the matter of their convergence. Mol Psychiatry 10:40-68; image 45.

Hashimoto R, Straub RE, Weickert CS, Hyde TM, Kleinman JE, Weinberger DR (2004) Expression analysis of neuregulin-1 in the dorsolateral prefrontal cortex in schizophrenia. Mol Psychiatry 9:299-307.

Hong EJ, McCord AE, Greenberg ME (2008) A biological function for the neuronal activity-dependent component of Bdnf transcription in the development of cortical inhibition. Neuron 60:610-624.

Huang YZ, Won S, Ali DW, Wang Q, Tanowitz M, Du QS, Pelkey KA, Yang DJ, Xiong WC, Salter MW, Mei L (2000) Regulation of neuregulin signaling by PSD-95 interacting with ErbB4 at CNS synapses. Neuron 26:443-455.

Kerber G, Streif R, Schwaiger FW, Kreutzberg GW, Hager G (2003) Neuregulin-1 isoforms are differentially expressed in the intact and regenerating adult rat nervous system. J Mol Neurosci 21:149-165.

Kim CH, Xiong WC, Mei L (2005) Inhibition of MuSK expression by CREB interacting with a CRE-like element and MyoD. Mol Cell Biol 25:5329-5338.

Knapska E, Kaczmarek L (2004) A gene for neuronal plasticity in the mammalian brain: Zif268/Egr-1/NGFI-A/Krox-24/TIS8/ZENK? Prog Neurobiol 74:183-211.

Kramer R, Bucay N, Kane DJ, Martin LE, Tarpley JE, Theill LE (1996) Neuregulins with an Ig-like domain are essential for mouse myocardial and neuronal development. Proc Natl Acad Sci U S A 93:4833-4838.

Kwon OB, Longart M, Vullhorst D, Hoffman DA, Buonanno A (2005) Neuregulin-1 reverses long-term potentiation at CA1 hippocampal synapses. J Neurosci 25:9378-9383.

Kwon OB, Paredes D, Gonzalez CM, Neddens J, Hernandez L, Vullhorst D, Buonanno A (2008) Neuregulin-1 regulates LTP at CA1 hippocampal synapses through activation of dopamine D4 receptors. Proc Natl Acad Sci U S A 105:15587-15592.

Lachman HM, Pedrosa E, Nolan KA, Glass M, Ye K, Saito T (2006) Analysis of polymorphisms in AT-rich domains of neuregulin 1 gene in schizophrenia. Am J Med Genet B Neuropsychiatr Genet 141B:102-109.

Law AJ, Lipska BK, Weickert CS, Hyde TM, Straub RE, Hashimoto R, Harrison PJ, Kleinman JE, Weinberger DR (2006) Neuregulin 1 transcripts are differentially expressed in schizophrenia and regulated by $5^{\prime}$ SNPs associated with the disease. Proc Natl Acad Sci U S A 103:6747-6752.

Law AJ, Kleinman JE, Weinberger DR, Weickert CS (2007) Diseaseassociated intronic variants in the ErbB4 gene are related to altered ErbB4 splice-variant expression in the brain in schizophrenia. Hum Mol Genet $16: 129-141$.

Li B, Woo RS, Mei L, Malinow R (2007) The neuregulin-1 receptor erbB4 controls glutamatergic synapse maturation and plasticity. Neuron 54:583-597.

Li T, Stefansson H, Gudfinnsson E, Cai G, Liu X, Murray RM, Steinthorsdottir V, Januel D, Gudnadottir VG, Petursson H, Ingason A, Gulcher JR, Stefansson K, Collier DA (2004) Identification of a novel neuregulin 1 at-risk haplotype in Han schizophrenia Chinese patients, but no association with the Icelandic/Scottish risk haplotype. Mol Psychiatry 9:698-704.

Lu HS, Chang D, Philo JS, Zhang K, Narhi LO, Liu N, Zhang M, Sun J, Wen J, Yanagihara D, Karunagaran D, Yarden Y, Ratzkin B (1995) Studies on the structure and function of glycosylated and nonglycosylated neu differentiation factors. Similarities and differences of the alpha and beta isoforms. J Biol Chem 270:4784-4791.

Ma L, Huang YZ, Pitcher GM, Valtschanoff JG, Ma YH, Feng LY, Lu B, Xiong WC, Salter MW, Weinberg RJ, Mei L (2003) Ligand-dependent recruit- ment of the ErbB4 signaling complex into neuronal lipid rafts. J Neurosci 23:3164-3175.

Mahanthappa NK, Anton ES, Matthew WD (1996) Glial growth factor 2, a soluble neuregulin, directly increases Schwann cell motility and indirectly promotes neurite outgrowth. J Neurosci 16:4673-4683.

Marchionni MA, Goodearl AD, Chen MS, Bermingham-McDonogh O, Kirk C, Hendricks M, Danehy F, Misumi D, Sudhalter J, Kobayashi K, Wroblewski D, Lynch C, Baldassare M, Hiles I, Davis JB, Hsuan JJ, Totty NF, Otsu M, McBurney RN, Waterfield MD, et al. (1993) Glial growth factors are alternatively spliced erbB2 ligands expressed in the nervous system. Nature 362:312-318.

Masand RP, El-Mofty SK, Ma XJ, Luo Y, Flanagan JJ, Lewis JS Jr (2011) Adenosquamous carcinoma of the head and neck: relationship to human papillomavirus and review of the literature. Head Neck Pathol 5:108-116.

McCarthy KD, de Vellis J (1980) Preparation of separate astroglial and oligodendroglial cell cultures from rat cerebral tissue. J Cell Biol 85:890-902.

Mei L, Xiong WC (2008) Neuregulin 1 in neural development, synaptic plasticity and schizophrenia. Nat Rev Neurosci 9:437-452.

Metsis M, Timmusk T, Arenas E, Persson H (1993) Differential usage of multiple brain-derived neurotrophic factor promoters in the rat brain following neuronal activation. Proc Natl Acad Sci U S A 90:8802-8806.

Meyer D, Yamaai T, Garratt A, Riethmacher-Sonnenberg E, Kane D, Theill LE, Birchmeier C (1997) Isoform-specific expression and function of neuregulin. Development 124:3575-3586.

Munafò MR, Thiselton DL, Clark TG, Flint J (2006) Association of the NRG1 gene and schizophrenia: a meta-analysis. Mol Psychiatry 11:539-546.

Murphy SN, Miller RJ (1989) Regulation of Ca + + influx into striatal neurons by kainic acid. J Pharmacol Exp Ther 249:184-193.

Nicodemus KK, Luna A, Vakkalanka R, Goldberg T, Egan M, Straub RE, Weinberger DR (2006) Further evidence for association between ErbB4 and schizophrenia and influence on cognitive intermediate phenotypes in healthy controls. Mol Psychiatry 11:1062-1065.

Norton N, Moskvina V, Morris DW, Bray NJ, Zammit S, Williams NM, Williams HJ, Preece AC, Dwyer S, Wilkinson JC, Spurlock G, Kirov G, Buckland P, Waddington JL, Gill M, Corvin AP, Owen MJ, O'Donovan MC (2006) Evidence that interaction between neuregulin 1 and its receptor erbB4 increases susceptibility to schizophrenia. Am J Med Genet B Neuropsychiatr Genet 141B:96-101.

Parlapani E, Schmitt A, Wirths O, Bauer M, Sommer C, Rueb U, Skowronek MH, Treutlein J, Petroianu GA, Rietschel M, Falkai P (2010) Gene expression of neuregulin-1 isoforms in different brain regions of elderly schizophrenia patients. World J Biol Psychiatry 11:243-250.

Petryshen TL, Middleton FA, Kirby A, Aldinger KA, Purcell S, Tahl AR, Morley CP, McGann L, Gentile KL, Rockwell GN, Medeiros HM, Carvalho C, Macedo A, Dourado A, Valente J, Ferreira CP, Patterson NJ, Azevedo MH, Daly MJ, Pato CN, et al. (2005) Support for involvement of neuregulin 1 in schizophrenia pathophysiology. Mol Psychiatry 10: $366-374,328$.

Pinkas-Kramarski R, Eilam R, Spiegler O, Lavi S, Liu N, Chang D, Wen D, Schwartz M, Yarden Y (1994) Brain neurons and glial cells express Neu differentiation factor/heregulin: a survival factor for astrocytes. Proc Natl Acad Sci U S A 91:9387-9391.

Pitcher GM, Beggs S, Woo RS, Mei L, Salter MW (2008) ErbB4 is a suppressor of long-term potentiation in the adult hippocampus. Neuroreport 19:139-143.

Prata DP, Breen G, Osborne S, Munro J, St Clair D, Collier DA (2009) An association study of the neuregulin 1 gene, bipolar affective disorder and psychosis. Psychiatr Genet 19:113-116.

Qiu Z, Ghosh A (2008) A brief history of neuronal gene expression: regulatory mechanisms and cellular consequences. Neuron 60:449-455.

Redmond L, Kashani AH, Ghosh A (2002) Calcium regulation of dendritic growth via CaM kinase IV and CREB-mediated transcription. Neuron 34:999-1010.

Rice FL, Van der Loos H (1977) Development of the barrels and barrel field in the somatosensory cortex of the mouse. J Comp Neurol 171:545-560.

Rimer M, Barrett DW, Maldonado MA, Vock VM, Gonzalez-Lima F (2005) Neuregulin-1 immunoglobulin-like domain mutant mice: clozapine sensitivity and impaired latent inhibition. Neuroreport 16:271-275.

Rio C, Rieff HI, Qi P, Khurana TS, Corfas G (1997) Neuregulin and erbB receptors play a critical role in neuronal migration. Neuron 19:39-50.

Schlaggar BL, O'Leary DD (1993) Patterning of the barrel field in somato- 
sensory cortex with implications for the specification of neocortical areas. Perspect Dev Neurobiol 1:81-91.

Sheng M, Thompson MA, Greenberg ME (1991) CREB: a Ca(2+)regulated transcription factor phosphorylated by calmodulin-dependent kinases. Science 252:1427-1430.

Shieh PB, Hu SC, Bobb K, Timmusk T, Ghosh A (1998) Identification of a signaling pathway involved in calcium regulation of BDNF expression. Neuron 20:727-740.

Shyu WC, Lin SZ, Chiang MF, Yang HI, Thajeb P, Li H (2004) Neuregulin-1 reduces ischemia-induced brain damage in rats. Neurobiol Aging 25:935-944.

Silberberg G, Darvasi A, Pinkas-Kramarski R, Navon R (2006) The involvement of ErbB4 with schizophrenia: association and expression studies. Am J Med Genet B Neuropsychiatr Genet 141B:142-148.

Sperk G (1994) Kainic acid seizures in the rat. Prog Neurobiol 42:1-32.

Sperk G, Lassmann H, Baran H, Kish SJ, Seitelberger F, Hornykiewicz O (1983) Kainic acid induced seizures: neurochemical and histopathological changes. Neuroscience 10:1301-1315.

Stefansson H, Sigurdsson E, Steinthorsdottir V, Bjornsdottir S, Sigmundsson T, Ghosh S, Brynjolfsson J, Gunnarsdottir S, Ivarsson O, Chou TT, Hjaltason O, Birgisdottir B, Jonsson H, Gudnadottir VG, Gudmundsdottir E, Bjornsson A, Ingvarsson B, Ingason A, Sigfusson S, Hardardottir H, et al. (2002) Neuregulin 1 and susceptibility to schizophrenia. Am J Hum Genet 71:877-892.

Stefansson H, Sarginson J, Kong A, Yates P, Steinthorsdottir V, Gudfinnsson E, Gunnarsdottir S, Walker N, Petursson H, Crombie C, Ingason A, Gulcher JR, Stefansson K, St Clair D (2003) Association of neuregulin 1 with schizophrenia confirmed in a Scottish population. Am J Hum Genet 72:83-87.

Steinthorsdottir V, Stefansson H, Ghosh S, Birgisdottir B, Bjornsdottir S, Fasquel AC, Olafsson O, Stefansson K, Gulcher JR (2004) Multiple novel transcription initiation sites for NRG1. Gene 342:97-105.

Tan W, Wang Y, Gold B, Chen J, Dean M, Harrison PJ, Weinberger DR, Law AJ (2007) Molecular cloning of a brain-specific, developmentally regulated neuregulin 1 (NRG1) isoform and identification of a functional promoter variant associated with schizophrenia. J Biol Chem 282: 24343-24351.

Tao X, Finkbeiner S, Arnold DB, Shaywitz AJ, Greenberg ME (1998) Ca2+ influx regulates BDNF transcription by a CREB family transcription factor-dependent mechanism. Neuron 20:709-726.

Thomson PA, Christoforou A, Morris SW, Adie E, Pickard BS, Porteous DJ, Muir WJ, Blackwood DH, Evans KL (2007) Association of Neuregulin 1 with schizophrenia and bipolar disorder in a second cohort from the Scottish population. Mol Psychiatry 12:94-104.

Timmusk T, Palm K, Metsis M, Reintam T, Paalme V, Saarma M, Persson H (1993) Multiple promoters direct tissue-specific expression of the rat BDNF gene. Neuron 10:475-489.

Ting AK, Chen Y, Wen L, Yin DM, Shen C, Tao Y, Liu X, Xiong WC, Mei L
(2011) Neuregulin 1 promotes excitatory synapse development and function in GABAergic interneurons. J Neurosci 31:15-25.

Trachtenberg JT, Thompson WJ (1996) Schwann cell apoptosis at developing neuromuscular junctions is regulated by glial growth factor. Nature 379:174-177.

Wen L, Lu YS, Zhu XH, Li XM, Woo RS, Chen YJ, Yin DM, Lai C, Terry AV Jr, Vazdarjanova A, Xiong WC, Mei L (2010) Neuregulin 1 regulates pyramidal neuron activity via ErbB4 in parvalbumin-positive interneurons. Proc Natl Acad Sci U S A 107:1211-1216.

West AE, Griffith EC, Greenberg ME (2002) Regulation of transcription factors by neuronal activity. Nat Rev Neurosci 3:921-931.

Wolpowitz D, Mason TB, Dietrich P, Mendelsohn M, Talmage DA, Role LW (2000) Cysteine-rich domain isoforms of the neuregulin-1 gene are required for maintenance of peripheral synapses. Neuron 25:79-91.

Woo RS, Li XM, Tao Y, Carpenter-Hyland E, Huang YZ, Weber J, Neiswender H, Dong XP, Wu J, Gassmann M, Lai C, Xiong WC, Gao TM, Mei L (2007) Neuregulin-1 enhances depolarization-induced GABA release. Neuron 54:599-610.

Wu H, Friedman WJ, Dreyfus CF (2004) Differential regulation of neurotrophin expression in basal forebrain astrocytes by neuronal signals. J Neurosci Res 76:76-85.

Xu Z, Jiang J, Ford G, Ford BD (2004) Neuregulin-1 is neuroprotective and attenuates inflammatory responses induced by ischemic stroke. Biochem Biophys Res Commun 322:440-446.

Yang JZ, Si TM, Ruan Y, Ling YS, Han YH, Wang XL, Zhou M, Zhang HY, Kong QM, Liu C, Zhang DR, Yu YQ, Liu SZ, Ju GZ, Shu L, Ma DL, Zhang D (2003) Association study of neuregulin 1 gene with schizophrenia. Mol Psychiatry 8:706-709.

Zafra F, Hengerer B, Leibrock J, Thoenen H, Lindholm D (1990) Activity dependent regulation of BDNF and NGF mRNAs in the rat hippocampus is mediated by non-NMDA glutamate receptors. EMBO J 9:3545-3550.

Zhang L, Fletcher-Turner A, Marchionni MA, Apparsundaram S, Lundgren KH, Yurek DM, Seroogy KB (2004) Neurotrophic and neuroprotective effects of the neuregulin glial growth factor- 2 on dopaminergic neurons in rat primary midbrain cultures. J Neurochem 91:1358-1368.

Zhao X, Shi Y, Tang J, Tang R, Yu L, Gu N, Feng G, Zhu S, Liu H, Xing Y, Zhao S, Sang H, Guan Y, St Clair D, He L (2004) A case control and family based association study of the neuregulin1 gene and schizophrenia. J Med Genet 41:31-34.

Zheng Y, Watakabe A, Takada M, Kakita A, Namba H, Takahashi H, Yamamori T, Nawa H (2009) Expression of ErbB4 in substantia nigra dopamine neurons of monkeys and humans. Prog Neuropsychopharmacol Biol Psychiatry 33:701-706.

Zuliani R, Moorhead TW, Bastin ME, Johnstone EC, Lawrie SM, Brambilla P, O'Donovan MC, Owen MJ, Hall J, McIntosh AM (2011) Genetic variants in the ErbB4 gene are associated with white matter integrity. Psychiatry Res 191:133-137. 